\title{
PENGEMBANGAN BUKU TEKS KELAS V SEKOLAH DASAR BERBASIS TEMATIK DENGAN MODEL MULTIPLE GAMES
}

\author{
Rosyidah Umami Octavia ${ }^{1}$, Bambang Yulianto ${ }^{2}$, Wahyu Sukartiningsih ${ }^{3}$ \\ Pendidikan Dasar, Pascasarjana Universitas Negeri Surabaya
}

\begin{abstract}
Abstrak
Penelitian ini merupakan penelitian pengembangan yang bertujuan untuk membantu guru membuat siswa aktif dan meningkatkan hasil belajar siswa kelas V SD dang menghasilkan produk berupa buku teks dengan model multiple games agar proses pembelajaran menjadi menyenangkan bagi siswa.

Penelitian ini dilakukan di kelas V SDN Pucang IV Sidoarjo. Penelitian ini dilaksanakan dalam tiga tahap, yaitu pendefinisian, perancangan, dan pengembangan. Hasil penelitian yang diperoleh sebagai berikut: (1) aktivitas guru sangat baik dan optimal; (2) respons guru menunjukkan sangat baik dan antusias dalam menerapkan pembelajaran; (3) aktivitas siswa menunjukkan bahwa secara klasikal sangat aktif; (4) respons siswa menunjukkan bahwa siswa memberikan respons yang sangat baik dan siswa antusias; (5) hasil belajar siswa secara klasikal siswa telah mencapai ketuntasan belajar berdasarkan KKM yang telah ditetapkan; (6) hambatan yang ditemukan adalah kelas menjadi gaduh sehingga dapat mengganggu konsentrasi siswa, akan tetapi hambatan yang ditemukan dapat segera diatasi agar proses pembelajaran dapat berjalan dengan lancar.

Berdasarkan hasil penelitian, disimpulkan bahwa penelitian ini sebagai sumbangan ilmiah dalam bidang pendidikan tentang pengembangan model pembelajaran inovatif yang menghasilkan produk berupa buku teks dengan model multiple games sehingga dapat diterapkan di SD untuk memotivasi guru dan membuat siswa aktif.
\end{abstract}

Kata Kunci: Buku Teks dan Model Multiple Games

\begin{abstract}
This study was development study which purpose to help teacher made active students and improved their achievement which produced text book with multiple games model in order to the teaching and learning process became fun.

This study conducted on the $5^{\text {th }}$ grade in pucang IV Sidoarjo. This study conducted in three steps consist of defining, desaigning, and developing. The result of this study were: (1) teacher's very good and optimally; (2) teacher's response showed very good response and teacher's attitude can accept learning innovation; (3) students' activities showed that classically active;(4) students' response showed very good response and students were enthusiastic; (5) students' classically students were passed the test based on KKM; (6) the difficulties showed through learning process using text book with multiple games model in limited test and wide test showed that class became crowded and could disturb students' focus, but the difficulties that had been found can be solved in order to learning process run smoothly.

Based on the result of the study, can be include that this study become a reference in education field about development model innovative learning that produce a text book with multiple games model, so that can be implemented on elementary school to motivate teacher and make students active and became confidence in delivering their own opinion through learning process.
\end{abstract}

\section{PENDAHULUAN}

\section{A. Latar Belakang}

Pendidikan

diharapkan dapat mengembangkan kualitas generasi muda dalam berbagai aspek yang dapat mengurangi penyebab berbagai masalah budaya dan karakter bangsa. Keinginan masyarakat dan kepedulian pemerintah mengenai pendidikan budaya dan karakter bangsa akhirnya berakumulasi pada kebijakan pemerintah mengenai pendidikan budaya dan karakter bangsa dan menjadi salah satu program unggulan pemerintah.

Salah satu upaya pemerintah adalah dengan mengimplementasikan kurikulum 2013 yang lebih menekankan pada perkembangan afektif peserta didik. Model pembelajaran yang dikembangkan pada kurikulum 2013 adalah model pembelajaran tematik. Dengan model pembelajaran ini, anak tingkat SD akan belajar sesuai dengan tema yang dipilih oleh guru secara teratur tiap minggu.

Sejalan dengan diberlakukannya kurikulum 2013, maka perlu adanya upaya persiapan yang baik. Sesuai dengan Undangundang nomor 14 tahun 2005 pasal 20 tentang guru dan dosen, bahwa guru melaksanakan tugas keprofesionalan berkewajiban untuk merencanakan pembelajaran, melaksanakan proses pembelajaran yang bermutu, serta menilai dan mengevaluasi hasil pembelajaran. 
Berpedoman dengan undang-undang tersebut, peneliti menganggap perlu untuk mengembangkan komponen kurikulum berupa buku teks. Hal tersebut dikarenakan setiap daerah memiliki kebutuhan yang berbeda-beda dalam mempersiapkan pembelajaran di kelas.

Namun pada kenyataannya dalam implementasi kurikulum 2013 terdapat beberapa masalah. Salah satu masalah yang sering dihadapi oleh guru dalam kegiatan pembelajaran adalah guru kurang leluasa selama proses pembelajaran karena guru harus melakukan kegiatan pembelajaran seperti apa yang telah dituliskan dalam buku guru tersebut. Guru terfokus pada kegiatan pembelajaran yang dirancang pemerintah tanpa melihat situasi dan kondisi serta karakter peserta didik selama proses pembelajaran berlangsung.

Hal ini sangat bertolak belakang dengan PP nomor 19 tahun 2005 Pasal 20 yang menyatakan bahwa guru diharapkan dapat mengembangkan materi pembelajaran sendiri yang kemudian dipertegas melalui Peraturan Menteri Pendidikan Nasioanl (Permendiknas) nomor 41 tahun 2007 tentang Standar Proses yang antara lain mengatur tentang perencanaan proses pembelajaran yang mensyaratkan bagi pendidik pada satuan pendidikan untuk mengembangkan rencana pelaksanaan pembelajaran (RPP). Salah satu elemen dalam RPP adalah sumber belajar. Dengan demikian guru diharapkan untuk mengembangkan bahan pembelajaran sebagai salah satu sumber belajar, yaitu berupa buku teks.

Dalam menentukan buku teks, sudah menjadi tugas guru untuk memilih dan mengembangkan materi pokok yang terdapat dalam buku siswa kurikulum 2013 yang sudah ada sehingga menjadi buku teks yang lengkap. Selain itu, bagaimana cara memanfaatkan buku teks juga merupakan hal yang harus diperhatikan. Pemanfaatan yang dimaksud adalah bagaimana cara mengajarkannya ditinjau dari pihak guru dan cara mempelajarinya ditinjau dari pihak siswa.

Buku teks atau materi pembelajaran secara garis besar terdiri atas pengetahuan, keterampilan, dan sikap yang harus dipelajari siswa dalam rangka mencapai tujuan pembelajaran yang telah ditentukan. Secara terperinci, jenis-jenis materi pembelajaran terdiri atas pengetahuan (fakta, konsep, prinsip, prosedur), keterampilan, dan sikap atau nilai. Buku teks merupakan salah satu komponen sistem pembelajaran yang memegang peranan penting dalam membantu siswa mencapai tujuan pembelajaran yang telah ditentukan. Dengan menerapkan buku teks yang telah dikembangkan tersebut, diharapkan diperoleh alternatif bagi guru dalam menyampaikan suatu materi pembelajaran sehingga proses belajar mengajar akan berjalan lebih optimal dan bervariasi yang pada akhirnya hasil belajar maupun aktivitas peserta didik diharapkan juga meningkat.

Selain mengembangkan buku teks siswa berbasis tematik sesuai dengan kurikulum 2013, peneliti juga berupaya untuk mencari alternatif pelaksanaan pembelajaran yang dapat mengakomodasi karakteristik siswa. Maka dari itu untuk memenuhi kebutuhan tersebut, perlu menerapkan model pembelajaran multiple games.

Salah satu upaya untuk membuat siswa memahami materi serta belajar dengan menyenangkan, maka perlu dikembangkan buku teks kurikulum 2013 dengan menggunakan model multiple games.

Berdasarkan kenyataan dalam proses kegiatan pembelajaran dengan menggunakan kurikulum 2013, anak dituntut untuk memahami materi dalam waktu yang sudah ditentukan. Hal ini seolah-olah memaksa anak untuk menghafal tanpa diimbangi dengan pembelajaran yang menyenangkan sehingga anak dapat merasa nyaman ketika belajar. Proses pembelajaran yang seperti ini akan membuat anak menjadi jenuh ketika belajar di dalam kelas.

Berkaitan dengan penjelasan diatas, maka perlu ada sebuah model pembelajaran inovatif yang dapat membuat anak dapat belajar sambil bermain sesuai dengan karakteristik anak sekolah dasar yang masih dalam tahap bermain, maka peneliti tertarik untuk melakukan penelitian dengan judul "Pengembangan Buku Teks Kelas V Sekolah Dasar Berbasis Tematik dengan Model Multiple Games ".

\section{B. Masalah Penelitian}

\section{1) Ruang Lingkup Penelitian}

Ruang lingkup pada penelitian ini adalah pengembangan buku teks kelas $\mathrm{V}$ Sekolah Dasar berbasis tematik dengan model multiple games. Pengembangan buku teks bahasa Indonesia untuk kelas V SD mencakup 3 subtema. Setiap subtema terdiri atas enam pembelajaran yang memuat beberapa mata pelajaran diantaranya bahasa Indonesia, matematika, Ilmu Pengetahuan Alam, Ilmu Pengetahuan Sosial, Seni Budaya dan Prakarya, dan Pendidikan Jasmani Olahraga dan Kesehatan, dan Pendidikan Pancasila dan Kewarganegaraan. 
Berbasis tematik dalam pengembangan buku teks yaitu selalu memunculkan tema dalam setiap pembelajaran.

Proses pembelajaran yang baik adalah yang berpusat pada siswa dengan menyenangkan. Salah satu cara yang dapat digunakan oleh guru untuk menciptakan pembelajaran yang menyenangkan adalah dengan melakukan beberapa permainan selama proses pembelajaran. Hal ini dimaksudkan agar anak tidak merasa jenuh belajar di kelas. Multiple Games adalah pengkolaborasian beberapa permaian yang dapat dilakukan bersama anak-anak sebagai variasi dalam pembelajaran. Setiap permainan yang dilaksanakan dalam kegiatan pembelajaran harus secara langsung dapat menunjang tercapainya tujuan pembelajaran.

\section{2) Batasan Masalah}

Penelitian ini secara umum diorientasikan untuk memfasilitasi proses pembelajaran. Bentuk pemfasilitasan yang dilaksanakan adalah pengembangan buku teks kelas V Sekolah Dasar. Berkait dengan luasnya ruang lingkup penelitian ini, maka dilakukan pembatasan masalah penelitian. Pembatasan dilakukan pada proses dan kualitas pengembangan.

Proses dan kualitas pengembangan mengacu pada BSNP 2007 tentang standar penulisan buku teks. Proses pengembangan buku diawali dengan memetakan KI dan KD. Pemetaan KI dan KD disesuaikan dengan tema yang telah ditetapkan di kurikulum 2013 untuk kelas V. KI dan KD tersebut kemudian dikembangkan menjadi beberapa indikator.

Buku teks yang dikembangkan nantinya akan diuji kualitasnya oleh validator dan calon pengguna buku teks. Penilaian dari validator dinilai dari segi kelayakan isi atau materi, kelayakan bahasa, kelayakan penyajian, dan kelayakan kegrafikaan. Kelayakan materi dan bahasa dilakukan oleh ahli bidang bahasa Indonesia, kelayakan penyajian dilakukan oleh ahli bidang pembelajaran, dan kelayakan kegrafikaan dilakukan oleh ahli bidang kegrafikaan. Penilaian dan masukan dari validator digunakan untuk merevisi buku teks. Hasil revisi yang telah diperbaiki siap digunakan untuk uji coba penelitian.

\section{3) Rumusan Masalah}

Berpijak dari batasan masalah sebagaimana telah dipaparkan diatas, maka didapatkan permasalahan secara umum dalam penelitian ini adalah bagaimana pengembangan buku teks kelas $\mathrm{V}$ sekolah dasar berbasis tematik dengan model multiple games. Permasalahan umum tersebut dirinci menjadi tiga perumusan khusus sebagai berikut.

1) Bagaimanakah proses pengembangan buku teks kelas $\mathrm{V}$ sekolah dasar berbasis tematik dengan model multiple games?

2) Bagaimanakah kualitas pengembangan buku teks kelas V sekolah dasar berbasis tematik dengan model multiple games?

Rumusan masalah tersebut dirinci sebagai berikut.

a) Bagaimanakah kualitas buku teks yang dikembangkan menurut unsur ketepatan materi?

b) Bagaimanakah kualitas buku teks yang dikembangkan menurut unsur penyajian?

c) Bagaimanakah kualitas buku teks yang dikembangkan menurut unsur kebahasaan?

d) Bagaimanakah kualitas buku teks yang dikembangkan menurut unsur kegrafikaan?

3) Bagaimanakah implementasi pengembangan buku teks kelas $\mathrm{V}$ sekolah dasar berbasis tematik dengan model multiple games?

Rumusan ini dirinci menjadi submasalah:

a) Bagaimana penggunaan buku teks yang dikembangkan dilihat dari sudut pandang guru yang dirinci sebagai berikut.

(1) Bagaimanakah aktivitas guru dalam pengimplementasian buku teks yang dikembangkan?

(2) Bagaimanakah respons guru dalam pengimplementasian buku teks yang dikembangkan?

b) Bagaimana penggunaan buku teks yang dikembangkan dilihat dari sudut pandang siswa yang dirinci sebagai berikut.

(1) Bagaimanakah aktivitas siswa dalam pengimplementasian buku teks yang dikembangkan?

(2) Bagaimanakah respons siswa dalam pengimplementasian buku teks yang dikembangkan? 
(3) Bagaimanakah hasil belajar siswa dalam pengimplementasian buku teks yang dikembangkan?

c) Apa faktor penghambat dalam pengimplementasian buku teks yang dikembangkan?

d) Apa faktor pendukung pengimplementasian buku teks yang dikembangkan?

\section{Tujuan Penelitian}

Penelitian ini secara umum bertujuan untuk mengembangkan pengembangan buku teks kelas V sekolah dasar berbasis tematik dengan model multiple games. Adapun tujuan umum tersebut dirinci menjadi tiga tujuan khusus sebagai berikut.

1. Mendeskripsikan proses pengembangan buku teks kelas $\mathrm{V}$ sekolah dasar berbasis tematik dengan model multiple games.

a) Mendeskripsikan Mendeskripsikan kualitas buku teks yang dikembangkan menurut unsur ketepatan materi.

b) Mendeskripsikan kualitas buku teks yang dikembangkan menurut unsur penyajian.

c) Mendeskripsikan kualitas buku teks yang dikembangkan menurut unsur kebahasaan.

2. Mendeskripsikan kualitas buku teks yang dikembangkan menurut unsur kegrafikaan.kualitas pengembangan buku teks kelas $\mathrm{V}$ sekolah dasar berbasis tematik dengan model multiple games, yang dirinci berdasarkan sebagai berikut.

3. Mendeskripsikan implementasi pengembangan buku teks kelas $\mathrm{V}$ sekolah dasar berbasis tematik dengan model multiple games yang dirinci menjadi sebagai berikut.

a) Mendeskripsikan penggunaan buku teks yang dikembangkan dilihat dari sudut pandang guru yang dirinci sebagai berikut.

(1) Mendeskripsikan aktivitas guru dalam pengimplementasian buku teks yang dikembangkan.

(2) Mendeskripsikan respons guru dalam pengimplementasian buku teks yang dikembangkan.

b) Mendeskripsikan penggunaan buku teks yang dikembangkan dilihat dari sudut pandang siswa yang dirinci sebagai berikut.
(1) Mendeskripsikan aktivitas siswa dalam pengimplementasian buku teks yang dikembangkan.

(2) Mendeskripsikan respons siswa dalam pengimplementasian buku teks yang dikembangkan.

(3) Mendeskripsikan hasil belajar siswa dalam pengimplementasian buku teks yang dikembangkan.

c) Mendeskripsikan faktor penghambat dalam pengimplementasian buku teks yang dikembangkan.

d) Mendeskripsikan faktor pendukung pengimplementasian buku teks yang dikembangkan.

\section{Manfaat Penelitian}

Manfaat yang diharapkan dari hasil penelitian ini sebagai berikut.

1. Manfaat teoretis

Hasil penelitian ini diharapkan memberikan manfaat sebagai berikut.

a. Dapat digunakan sebagai wacana dan bahan pertimbangan untuk penelitian lebih lanjut

2. Manfaat praktis

Hasil penelitian ini diharapkan memberikan manfaat sebagai berikut.

a. Bagi guru dapat digunakan sebagai acuan mengembangkan buku teks kelas $\mathrm{V}$ sekolah dasar berbasis tematik dengan model multiple games

b. Bagi lembaga yang diteliti sebagai bahan pertimbangan dalam menentukan buku teks yang berkualitas dan dapat membentuk siswa memiliki karakteristik yang unggul juga motivasi guru untuk selalu memperkaya bahan pembelajaran

c. Bagi peneliti, hasil penelitian ini diharapkan dapat memberikan motivasi untuk dapat mengembangkan buku teks lain sesuai dengan kebutuhan dan karakteristik siswa

\section{E. Definisi Istilah}

Beberapa batasan dalam penelitian pengembangan buku teks kelas kelas $\mathrm{V}$ sekolah dasar berbasis tematik dengan model multiple games diuraikan sebagai berikut.

Proses pengembangan adalah serangkaian proses atau kegiatan yang dilaksanakan selama pengembangan buku teks berdasarkan tahapan model four $D$ yaitu define (pendefinisian), design 
(perancangan), develop (pengembangan), dan disseminate (penyebaran).

Kualitas buku teks adalah kelayakan buku teks yang didasarkan pada kevalidan, kepraktisan, dan keefektifan.

Implementasi adalah proses penerapan hasil buku teks yang dikembangkan untuk proses pembelajaran di kelas.

Buku teks adalah buku yang disusun untuk kepentingan proses pembelajaran baik yang bersumber dari hasil penelitian atau hasil dari sebuah pemikiran tentang kajian bidang tertentu yang kemudian dirumuskan menjadi bahan pembelajaran. Buku teks merupakan salah satu bahan ajar yang berupa bahan cetak.

Tematik merupakan pendekatan pembelajaran dalam bentuk tema yang terintegrasi ke seluruh mata pelajaran yang penyampaian materi ajar tidak disampaikan berdasarkan mata pelajaran tertentu.

Multiple Games adalah pengkolaborasian beberapa permainan yang dapat dilakukan anak-anak sebagai variasi dalam pembelajaran.

Aktivitas siswa adalah kegiatan yang terjadi selama proses pembelajaran seperti bertanya, mengajukan pendapat, mengerjakan tugas, dapat menjawab pertanyaan guru dan bisa bekerjasama dengan siswa lain, serta tanggung jawab terhadap tugas yang diberikan dalam pengimplementasian buku teks yang dikembangkan.

Hasil belajar siswa adalah hasil yang diperoleh siswa setelah terjadinya proses pembelajaran yang ditunjukkan dengan nilai tes yang diberikan oleh guru setiap selesai memberikan materi pelajaran pada satu pokok bahasan dalam pengimplementasian buku teks yang dikembangkan.

Faktor pendukung adalah segala sesuatu yang dapat menunjang keberhasilan untuk mencapai tujuan yang diharapkan.

Faktor penghambat adalah segala sesuatu yang dapat menghambat keberhasilan untuk mencapai tujuan yang diharapkan.

\section{F. Hasil Pengembangan}

Hasil penelitian ini adalah pengembangan buku teks kelas V sekolah dasar berbasis tematik dengan model multiple games. Buku teks ini disusun berdasarkan kurikulum 2013. Spesifikasi produk yang diharapkan adalah berupa fisik dan konten isi yang akan diuraikan sebagai berikut.

1. Fisik buku hasil pengembangan

Adapun bentuk fisik dari buku teks tersebut meliputi:

(a) sampul depan dan belakang menggunakan kertas film glossy A4;

(b) isi buku menggunakan kertas ukuran A4 70 gram $(210 \times 297 \mathrm{~mm})$;

(c) kurang lebih memuat 90 halaman yang terdiri atas sampul muka, isi buku, dan sampul belakang;

(d) tipografi buku meliputi (1) warna yang digunakan untuk huruf dan ilustrasi adalah warna hitam dan beberapa warna lainnya, (2) bentuk huruf yang digunakan (bold, italic, all capital, small, capital), (3) jenis huruf yang diguankan (miandra GD, times new rowman, calibri, dan comic sains $M S$ ), (4) tata letak pengaturan huruf menggunakan spasi 1,5 dan 2,0 antar kata, (5) font yang digunakan pada judul adalah 16 untuk judul dan yang digunakan dalam teks adalah 12, (6) terdapat beberapa gambar yang sesuai dengan isi materi pelajaran, (7) batas atas buku $3 \mathrm{~cm}$, batas kiri buku $4 \mathrm{~cm}$, batas bawah buku $4 \mathrm{~cm}$, dan batas kanan buku $3 \mathrm{~cm}$.

2. Isi buku hasil pengembangan

Berdasarkan isinya, pengembangan buku teks berbasis tematik ini meliputi:

(a) isi buku kurang lebih 90 halaman yang terdiri atas halaman judul, kata pengantar, daftar isi, materi bahan ajar, evaluasi, dan daftar pustaka;

(b) buku teks ini mencakup materi pelajaran kelas $\mathrm{V}$ sesuai dengan kurikulum 2013;

(c) terdapat beberapa perintah untuk siswa dalam proses pembelajaran dengan mengkolaborasi permainan;

(d) materi dan tugas yang disajikan dikembangkan dari kompetensi dasar;

(e) buku teks berisi beberapa mata pelajaran yang dikolaborasikan menjadi satu berdasarkan tema;

(f) terdiri atas 1 tema dengan 3 subtema, masing-masing subtema terdiri atas 6 pembelajaran; 
(g) istilah yang digunakan disesuaikan dengan kemampuan siswa kelas $\mathrm{V}$ Sekolah Dasar;

(h) bahasa yang digunakan bersifat dialogis dan komunikatif agar mudah dipahami siswa; panjang kalimat minimal terdiri atas empat kata dan maksimal sepuluh kata.

\section{METODE PENELITIAN}

\section{A. Jenis Penelitian}

Penelitian ini merupakan penelitian pengembangan. Dalam penelitian ini dilakukan pengembangan buku teks berbasis tematik dengan model multiple games di kelas $\mathrm{V}$ sekolah dasar. Buku teks hasil pengembangan ini akan di uji cobakan dan hasil uji coba ini akan dianalisis secara deskriptif kualitatif untuk menjawab rumusan masalah.

\section{B. Subjek Penelitian}

Subjek dalam penelitian ini adalah guru kelas V dan siswa kelas V SDN Pucang IV Sidoarjo. Jumlah siswa yang ikut terlibat dalam penelitian ini sebanyak 37 siswa.

\section{Desain Penelitian}

Desain penelitian ini mengikuti teori Four-D Models yang dikembangkan oleh Thiagarajan dan Sammel (dalam Trianto, 2007:65). Model pengembangan ini terdiri atas empat tahap, yaitu tahap define, design, develop, dan desseminate atau diadaptsi menjadi 4-P yaitu pendefinisian, perancangan, pengembangan, dan penyebaran. Peneliti menggunakan rancangan pengembangan ini karena lebih terperinci dan sistematis sehingga memudahkan untuk melakukan proses pengembangan buku teks.

Dalam penelitian ini pengembangan buku teks disederhanakan hanya sampai pada tahap develop tanpa tahap dessiminate, sehingga buku teks yang telah dikembangkan hanya digunakan pada sekolah uji coba saja, tanpa disebarkan pada sekolah lain.

\section{Pengumpulan Data}

\section{Teknik Pengumpulan Data}

Teknik pengumpulan data yang digunakan dalam penelitian ini sebagai berikut.

a. Data untuk proses pengembangan buku teks diambil menggunakan teknik pemeteaan $\mathrm{KI}$, KD, indikator, buku teks, dan tema. Teknik validasi dilakukan oleh tim validator. Masukan dan saran dari tim validator digunakan sebagai salah satu rujukan untuk merevisi buku teks.

b. Data untuk kualitas produk buku teks dikumpulkan menggunakan teknik analisis deskriptif berdasarkan hasil validasi kedua.

c. Data untuk implementasi penggunaan buku teks dikumpulkan menggunakan teknik observasi yang dilakukan pada saat guru dan siswa menggunakan buku teks itu selama proses pembelajaran untuk mengetahui aktivitas guru dan siswa. Teknik angket digunakan untuk mengetahui respons guru dan siswa setelah menggunakan buku teks. Teknik tes hasil belajar untuk mengetahui pencapaian tujuan pembelajaran siswa setelah menggunakan buku teks.

\section{Instrumen Pengumpulan Data}

Instrumen penelitian yang akan digunakan dalam penelitian ini sebagai berikut.

a. Instrumen pengumpulan data untuk proses pengembangan buku teks di kelas V SD.

1) Lembar pemetaan KI dan KD;

2) lembar validasi draf I buku teks untuk isi;

3) lembar validasi draf I buku teks untuk penyajian;

4) lembar validasi draf I buku teks untuk kebahsaan;

5) lembar validasi draf I buku teks untuk kegrafikaan.

b. Instrumen pengumpulan data untuk kualitas produk buku teks yang dikembangkan di kelas V SD.

1) Lembar validasi draf II buku teks untuk isi;

2) lembar validasi draf II buku teks untuk penyajian;

3) lembar validasi draf II buku teks untuk kebahsaan;

4) lembar validasi draf II buku teks untuk kegrafikaan.

c. Instrumen pengumpulan data untuk implementasi penggunaan buku teks yang dikembangkan di kelas V SD. 
1) Lembar observasi aktivitas guru dan siswa selama penggunaan draf II buku teks;

2) lembar angket respons penggunaan buku oleh guru dan siswa;

3) lembar tes hasil belajar siswa terhadap pencapaian tujuan pembelajaran.

\section{Prosedur Pengumpulan Data}

Prosedur yang digunakan dalam pengumpulan data untuk proses pengembangan buku teks, kualitas produk buku teks, dan implementasi penggunaan buku teks adalah sebagai berikut.

a.Prosedur pengumpulan data untuk proses pengembangan buku teks adalah 1) penggolongan karakteristik dan kebutuhan SD kelas 5; 2) pemetaan indikator secara umum dari Kompetensi Inti (KI) dan Kompetensi Dasar (KD); 3) pemetaan pemerolehan bahan ajar; 4) penulisan dan penyusunan draf $I ; 6$ ) validasi draf I oleh tim validator; 7) pengukuran hasil validasi draf I; 8) revisi I draf I dan penyuntingan; 9) persetujuan hasil revisi I draf I ke tim validator I menjadi draf II; 10) uji coba I draf II; 11) revisi II draf II; dan 12) uji coba II sebagai implementasi serta validasi draf II Revisi II untuk kualitas buku teks.

b.Prosedur pengumpulan data untuk kualitas buku teks adalah 1) penyerahan revisi II draf II oleh tim validator II; 2) proses validasi kualitas oleh tim validator II; 3 ) hasil pengukuran tim validator II merupakan data untuk mengetahui kualitas buku teks dalam penelitian.

c.Prosedur pengumpulan data untuk implementasi buku teks adalah 1) uji coba II draf II revisi II; 2) pengamatan aktivitas siswa selama uji coba berlangsung; dan 3) pengumpulan hasil pengamatan dan hasil belajar siswa.

\section{E. Penganalisisan Data}

Kegiatan penganalisisan data pada penelitian ini meliputi; 1) proses pengembangan buku teks; 2) kualitas produk buku teks yang dikembangkan; 3) implementasi penggunaan buku teks yang dikembangkan. Adapun penganalisisan data tersebut terdiri dari teknik dan prosedur sebagai berikut.

\section{Teknik Penganalisisan Data}

Analisis data pada penelitian ini dilakukan secara deskriptif. Analisis deskriptif berfungsi untuk memberikan, memaparkan, dan menyajikan informasi. Dalam penelitian ini, analisis data dilakukan dalam proses pengembangan buku teks, kualitas buku teks, dan pengimplementasian buku teks selama proses pembelajaran. Analisis data akan dijelaskan sebagai berikut.

a. Analisis data untuk proses pengembangan buku teks menggunakan teknik deskriptif kualitatif.

b.Analisis data untuk kualitas produk buku teks yang dikembangkan dilakukan dengan menggunakan teknik statistik deskriptif. Untuk skor yang didapatkan dari hasil validasi dapat dikategorikan pada tabel 3.1 berikut:

Tabel 3.1 Tabel Kategori Validasi

\begin{tabular}{|c|c|c|}
\hline $\begin{array}{c}\text { Rentang } \\
\text { Skor } \\
\text { Validasi }\end{array}$ & Kesimpulan & Keterangan \\
\hline $1,00-1,50$ & Tidak Baik & $\begin{array}{c}\text { Belum dapat } \\
\text { digunakan }\end{array}$ \\
\hline $1,60-2,50$ & Cukup Baik & $\begin{array}{c}\text { Dapat } \\
\text { digunakan } \\
\text { dengan banyak } \\
\text { revisi }\end{array}$ \\
\hline $2,60-3,50$ & Baik & $\begin{array}{c}\text { Dapat } \\
\text { digunakan } \\
\text { dengan sedikit } \\
\text { revisi }\end{array}$ \\
\hline $3,64-4,00$ & Sangat Baik & $\begin{array}{c}\text { Dapat } \\
\text { digunakan } \\
\text { dengan sedikit } \\
\text { revisi }\end{array}$ \\
\hline
\end{tabular}

Dari skor yang diperoleh maka dijadikan persentase dengan menggunakan rumus sebagai berikut.

$P K=\frac{\sum K x}{\sum K y} x 100 \%$

Keterangan

PK = nilai persentase kualitas buku teks

$\mathrm{Kx}=$ skor perolehan dari komponen kualitas buku teks

Ky = skor total dari komponne kualitas buku teks

Interval persentase yang digunakan menurut linkert (dalam Sugiono, 2010;254) sebagai berikut. 
1. $85 \%$ - $100 \%$ dengan kriteria sangat berkualitas

2. $75 \%-84 \%$ dengan kriteria berkualitas

3. $60 \%$ - $74 \%$ dengan kriteria cukup berkualitas

4. $40 \%-59 \%$ dengan kriteria tidak berkualitas

5. $39 \%-0 \%$ dengan kriteria sangat tidak berkualitas

c. Analisis data untuk implementasi penggunaan buku teks yang dikembangkan dilakukan melalui teknik analisis deskriptif dari hasil observasi terhadap aktivitas guru dan siswa, respons guru dan siswa, serta hasil belajar siswa selama penggunaan draf II buku teks.

\section{Instrumen Penganalisisan Data}

Instrumen-instrumen

untuk

menganalisis data-data dalam penelitian ini adalah sebagai berikut:

a.Instrumen penganalisisan data untuk proses pengembangan buku teks;

1) lembar analisis pemodelan indikator $\mathrm{KI}$ dan $\mathrm{KD}$;

2) lembar pemetaan kerangka bahan buku teks;

3) lembar analisis deskriptif terhadap hasil validasi draf I;

4) lembar analisis deskriptif kualitas hasil belajar selama proses pembelajaran uji coba I.

b. Instrumen penganalisisan data untuk kualitas buku teks;

lembar analisis deskriptif terhadap hasil validasi draf II.

c. Instrumen penganalisisan data untuk implementasi bukuajar;

1) lembar analisis deskriptif kualitatif hasil observasi terhadap siswa selama penggunaan draf II buku teks;

2) lembar analisis deskriptif kualitas hasil belajar siswa selama pembelajaran uji coba II atau implementasi.

\section{Prosedur Penganalisisan Data}

Prosedur penganalisisan data pada penelitian ini akan dijabarkan sebagai berikut.

a.Penganilisan data untuk proses pengembangan buku teks meliputi: 1) modifikasi indikator berdasarkan KI dan $\mathrm{KD}$; 2) seleksi buku teks yang digunakan siswa; dan 3) analisis hasil penilaian dari tim validator I atas draf I buku teks.
b.Prosedur penganalisisan data untuk kualitas produk buku teks yang dikembangkan meliputi 1) validasi draf I oleh tim validator I; 2) uji coba draf I; 3) analisis hasil validasi tim validator II atas draf II dimana draf I telah divalidasi serta disetujui oleh tim validator I dan telah diuji cobakan.

c.Prosedur penganalisisan data untuk implementasi penggunaan buku teks yang dikembangkan meliputi 1) analisis hasil observasi terhadap aktivitas guru dan siswa; 2) analisis hasil observasi terhadap respons guru dan siswa saat menggunakan buku teks yang dikembangkan selama proses pembelajaran; 3 ) analisis hasil belajar siswa setelah menggunakan buku teks yang dikembangkan dari hasil penilaian tugas maupun pemberian soal-soal latihan yang diberikan guru. Analisis data pada penelitian ini disajikan dalam bentuk persentase untuk mengetahui tingkat aktivitas siswa dan peningkatan hasil belajar siswa.

1) Untuk mencari persentase skor aktivitas siswa selama proses pembelajaran menggunakan rumus:

Hasil akhir $=\frac{\text { jumlah skoryang diperoleh }}{\text { jumlah skor tertinggi }} \times 100 \%$

Tabel 3.2 Kriteria Persentase Rata-Rata

Aktifitas Siswa

\begin{tabular}{|c|c|c|}
\hline No & $\begin{array}{c}\text { Persentase } \\
\text { Keaktifan }\end{array}$ & Kriteria Keaktifan \\
\hline 1 & $85 \%-100 \%$ & Sangat aktif \\
\hline 2 & $75 \%-84 \%$ & Aktif \\
\hline 3 & $60 \%-74 \%$ & Cukup aktif \\
\hline 4 & $40 \%-59 \%$ & Tidak Aktif \\
\hline 5 & $39 \%-0 \%$ & Sangat Tidak Aktif \\
\hline
\end{tabular}

Sumber: (Slameto, 1999: 11)

2) Untuk mencari persentase ketuntasan hasil belajar siswa pada aspek kemampuan menulis menggunakan rumus sebagai berikut:

$\mathrm{P}=\frac{\mathrm{n}}{\mathrm{N}} \times 100 \%$

Keterangan:

$\mathrm{P}=$ Persentase ketuntatasan hasil belajar siswa

$\mathrm{n} \quad=$ Jumlah siswa yang memiliki skor 78 dari skor maksimal 100

$\mathrm{N}=$ Jumlah seluruh siswa

Tabel 3.3 Kategori Persentase Hasil Belajar Siswa 


\begin{tabular}{|c|c|}
\hline Persentase & Kategori \\
\hline $61 \% \leq \mathrm{P} \leq 100 \%$ & Tuntas \\
\hline $\mathrm{P}<60 \%$ & Tidak tuntas \\
\hline
\end{tabular}

Sumber: (Purwanto, 2001:103).

\section{III.HASIL PENELITIAN}

Pada proses pengembangan ini akan disajikan informasi yang diawali dari proses perencanaan hingga berupa buku teks yang siap digunakan untuk proses pembelajaran. Sebelum mengembangkan buku teks dengan model multiple games, ada empat tahapan sebagaimana pengembangan menurut Thiagarajan dalam Ibrahim (2001) yaitu tahap pendefinisian, perancangan, pengembangan, dan penyebaran. Namun, dalam penelitian ini pengembangan buku teks disederhanakan hanya sampai pada tahap pengembangan, sehingga buku teks yang telah dikembangkan hanya digunakan pada sekolah uji coba saja, tanpa disebarkan pada sekolah lain karena mengingat batasan waktu dan biaya.

Pada tahap pendefinisian peneliti melakukan beberapa tahapan yaitu analisis awal-akhir, analisis siswa, analisis konsep analisis tugas, dan perumusan tujuan pembelajaran. Tahap pendefinisian dilakukan pada bulan september 2014. Berdasarkan hasil pada tahap pendefinisian, menjadikan pelaksanaan pada tahap perancangan yang menghasilkan desain awal dari buku teks dengan model multiple games. Kegiatan yang dilakukan pada tahap perancangan yaitu kriteria tes, pemilihan media, penyusunan format buku ajar, dan desain awal buku teks.

Tahap perancangan dilakukan pada bulan Nopember 2014. Penyusunan desain awal buku teks menjadi akhir tahap perancangan dan menjadi dasar pelaksanaan tahap selanjutnya yaitu pengembangan. Pada tahap pengembangan terdiri atas serangkaian kegiatan yaitu validasi, revisi hasil validasi, dan uji coba. Pelaksanaan uji coba pada tahap pengembangan meliputi uji coba terbatas dan uji coba luas. Hasil tahap pengembangan yaitu penilaian ahli, uji coba terbatas, dan uji coba luas. Tahap pengembangan dilakukan pada bulan Februari 2015.

Hasil kualitas buku teks yang dikembangkan berdasarkan hasil validasi dari tim validator terdapat pada tabel 3.1 berikut.

Tabel 3.1 Hasil Validasi Tim Validator Keseluruhan

\begin{tabular}{|c|c|c|c|c|}
\hline No & $\begin{array}{c}\text { Komponen } \\
\text { penilaian }\end{array}$ & $\begin{array}{c}\text { Skor } \\
\text { total }\end{array}$ & $\begin{array}{c}\text { Skor } \\
\text { perolehan }\end{array}$ & $\begin{array}{c}\text { Rata- } \\
\text { rata }\end{array}$ \\
\hline
\end{tabular}

\begin{tabular}{|l|l|c|c|c|}
\hline 1 & Isi & 36 & 33 & 3,6 \\
\hline 2 & Penyajian & 40 & 37 & 3,7 \\
\hline 3 & Kebahasaan & 36 & 32 & 3,5 \\
\hline 4 & Kegrafikaan & 48 & 44 & 3,6 \\
\hline & $\sum=4$ & $\sum=$ & $\sum=141$ & $\sum=$ \\
& & 160 & & 3,6 \\
\hline
\end{tabular}

Berdasarkan hasil validasi para tim validator terhadap buku teks yang dikembangkan ini termasuk dalam kriteria layak untuk digunakan pada pembelajaran di kelas V SD.

Tabel 3.2Rekapitulasi Hasil Persentase Aktivitas Guru Selama Pembelajaran

\begin{tabular}{|c|c|c|c|c|c|c|}
\hline \multirow{2}{*}{$\begin{array}{l}\mathbf{N} \\
\mathbf{o}\end{array}$} & \multirow{2}{*}{$\begin{array}{l}\text { Pelaksana } \\
\text { an } \\
\text { Penelitian }\end{array}$} & \multicolumn{2}{|c|}{$\begin{array}{l}\text { Skor } \\
\text { Pengamat }\end{array}$} & \multicolumn{2}{|c|}{$\begin{array}{l}\text { Persentase } \\
\text { Pengamat } \\
\%\end{array}$} & \multirow{2}{*}{$\begin{array}{l}\text { Rata- } \\
\text { rata } \\
\text { Perse } \\
\text { ntase } \\
\% \\
\end{array}$} \\
\hline & & $\mathbf{P 1}$ & $\mathbf{P 2}$ & $\mathbf{P 1}$ & $\mathbf{P 2}$ & \\
\hline 1 & $\begin{array}{l}\text { Uji coba } \\
\text { terbatas }\end{array}$ & 111 & 112 & 95,6 & 96,5 & 96 \\
\hline 2 & $\begin{array}{l}\text { Uji coba } \\
\text { luas }\end{array}$ & 112 & 113 & 96,5 & 97,4 & 96,9 \\
\hline \multicolumn{6}{|c|}{ Persentase Keseluruhan \% } & 96,4 \\
\hline
\end{tabular}

Dari tabel 3.2 diatas dapat disimpulkan bahwa aktivitas guru selama proses pembelajaran pada uji coba terbatas skor pada pengamat 1 sebesar 111 dengan persentase 95,\%, sedangkan skor pada pengamat 2 sebesar 112 dengan persentase 96,5\%. Persentase rata-rata pada uji coba terbatas sebesar $96 \%$. Pada uji coba luas skor pada pengamat 1 sebesar 112 dengan persentase 96,5\%, sedangkan skor pada pengamat 2 sebesar 113 dengan persentase $97,4 \%$. Persentase rata-rata pada uji coba luas sebesar $96,9 \%$.

Dengan demikian persentase aktivitas guru selama proses pembelajaran pada uji coba terbatas dan uji coba luas sebesar $96,4 \%$ sehingga dinyatakan seluruhnya memenuhi kriteria yang ditentukan sehingga penggunaan buku teks dengan model multiple games yang diterapkan di dalam kelas dapat terlaksana secara optimal dan kemampuan guru dalam mengelola pembelajaran sangat aktif.

Tabel 3.2

Rekapitulasi Hasil Persentase Aktivitas Siswa

Selama Pembelajaran Secara Klasikal

\begin{tabular}{|c|c|c|c|c|c|c|}
\hline \multirow[t]{2}{*}{$\begin{array}{l}\mathbf{N} \\
\mathbf{0}\end{array}$} & \multirow{2}{*}{$\begin{array}{l}\text { Pelaksana } \\
\text { an } \\
\text { Penelitian }\end{array}$} & \multicolumn{2}{|c|}{$\begin{array}{l}\text { Skor } \\
\text { Penga } \\
\text { mat }\end{array}$} & \multicolumn{2}{|c|}{$\begin{array}{l}\text { Persentase } \\
\text { Pengamat } \\
\% \\
\end{array}$} & \multirow{2}{*}{$\begin{array}{l}\text { Rata- } \\
\text { rata } \\
\text { Perse } \\
\text { ntase }\end{array}$} \\
\hline & & $\mathbf{P}$ & $\mathbf{P}$ & P1 & P2 & \\
\hline
\end{tabular}




\begin{tabular}{|l|l|l|l|l|l|l|}
\hline & & $\mathbf{1}$ & $\mathbf{2}$ & & & $\%$ \\
\hline 1 & $\begin{array}{l}\text { Uji coba } \\
\text { terbatas }\end{array}$ & 82 & 81 & 97,6 & 96,4 & 97 \\
\hline 2 & $\begin{array}{l}\text { Uji coba } \\
\text { luas }\end{array}$ & 83 & 83 & 98,8 & 98,8 & 98,8 \\
\hline \multicolumn{3}{|l|}{ Persentase Keseluruhan \% } & 97,9 \\
\hline
\end{tabular}

Dari tabel 3.2 diatas dapat disimpulkan bahwa aktivitas siswa selama proses pembelajaran pada uji coba terbatas skor pada pengamat 1 pada dinyatakan seluruhnya memenuhi kriteria yang ditentukan sehingga penggunaan buku teks dengan model multiple games yang diterapkan di dalam kelas dapat terlaksana secara optimal dan siswa sangat aktif selama proses pembelajaran berlangsung.

\section{IV.PENUTUP}

\section{A. Simpulan}

Pada proses pengembangan buku teks terdapat tiga tahap dalam pengembangan model pembelajaran yang digunakan dalam penelitian ini, yaitu pendefinisian, perancangan, dan pengembangan. Kualitas pengembangan buku teks berdasarkan hasil validasi yang terdiri atas unsur ketepatan isi, penyajian, kebahasaan, dan kegrafikaan. Hasil implementasi buku teks dengan menggunakan model multiple games pada siswa kelas V SDN Pucang IV Sidoarjo menyatakan bahwa berdasarkan analisa aktivitas siswa dapat dikatakan aktivitas siswa dalam kegiatan pembelajaran telah mencerminkan aktivitas yang sesuai dengan tahap-tahap pembelajaran. Berdasarkan hasil respons siswa terhadap buku teks yang dikembangkan dengan model multiple games menyatakan bahwa respons yang diberikan siswa sangat baik dan siswa antusias selama proses pembelajaran berlangsung, sedangkan respons guru terhadap buku teks yang dikembangkan dengan model multiple games menyatakan bahwa respons yang diberikan guru sangat baik sehingga guru merasa antusias dalam menerapkan model pembelajaran tersebut.

\section{B. Saran}

Bagi guru hendaknya menggunakan buku teks dengan model multiple games dalam pembelajaran karena buku teks tersebut memiliki beberapa karakteristik yang terdapat pada anak usia sekolah dasar yaitu bermain dan melibatkan siswa secara aktif dalam proses pembelajaran. Bagi siswa kelas V, khususnya menggunakan buku teks dengan model multiple games dapat memotivasi dang mengaktifkan siswa selama proses pembelajaran berlangsung. Bagi peneliti lain yang tertarik dengan penelitian ini dapat dijadikan sumber referensi untuk dijadikan penelitian lanjutan dengan kelas yang berbeda atau pada materi yang lain.

\section{DAFTAR PUSTAKA}

Agung, Iskandar. (2010) Meningkatkan Kreativitas Pembelajaran bagi Guru. Jakarta: Bestari Buana Murni.

Dahar, Ratna Wilis. (1989) Teori-teori Belajar. Jakarta: Penerbit Erlangga

Degeng, Nyoman Sudana dan Miarso. (1993) Desain Pembelajaran Teori Keterapan. Malang. PPS IKIP Malang.

Departememen Pendidikan Nasional. (2003) Standar Penilaian Buku Pelajaran Bahasa dan Sastra Indonesia. Jakarta: Pusat Perbukuan

Departemen Pendidikan Nasional. (2008) Panduan Pengembangan Bahan Ajar. Jakarta: Depdiknas.

Departemen Pendidikan Nasional. (2013) Draf Kurikulum 2013 untuk Sekolah Dasar SD/MI. Jakarta: Balitbang.

DePorter, Bobbi. (2009) Quantum Writer: Menulis Lebih Mudah, Tanpa Stres, dengan Hasil Lebih Baik. Cetakan ke-2. Diterjemahkan oleh Lovely: Bandung: Mizan Media Utama.

Dimyati dan Mujiono. (2002) Belajar dan Pembelajaran. Jakarta: Rineka Cipta.

Fogarty, Robin. (1991) The Mindful School How to Integrate The Curricula. USA:IRI/Skylight Publishing.

Gafur. (2004) Pedoman Penyusunan Materi Pembelajaran. (Instructional Material). Jakarta: Depdiknas.

Hernawan, Asep. (2009) Pembelajaran Terpadu di $S D$. Jakarta: Universitas Terbuka.

Ismanto, Hadi. (2012) "Pengembangan Model PKn SD Kelas IV Pada Pokok Bahasan Globalisasi Berorientasi Pendidikan Karakter". Tesis, Tidak diterbitkan. Surabaya: PPs Pendidikan Dasar.

Johnson D.W and Johnson R.T. (1994) Learning Together and Alone. Fourth Edition. Massachusset : Allyn and Bacon Publisher.

Kagan, Richard Mark. (1992) Storytelling and Game Therapy for Children in Placement. Parsons Child and Family Center, Albany: New York. Child Care Quality 11(4). 
Kurniawan, Deni. (2011) Pembelajaran Terpadu Teori, Praktek, dan Penilaian. Bandung: CV Pustaka Cendekia Utama.

Majid, A. (2008) Perencanaan Pembelajaran. Bandung: PT. Rosdakarya.

Muslich, Masnur. (2010) Texs Book Writing (Dasar-Dasar Pemahaman Penulisan, dan Pemakaian Buku Teks). Jogjakarta: Ar-ruzz Media

Nieveen, Nieenke. (1999). Prototyping to Reach Product Quality. In Jan Vanden Akker, R.M. Brunc, K. Gutafson, N Nieveen \& TJ Plom (Eds). Design approaches and tool in education and training. Dorgerecht, The Netherland Kluwer Academic Publiser.

Nur, M. (2008) Pemotivasian Siswa Untuk Belajar.Surabaya: Unesa, University, Press.

Notodiputro, Khairil Anwar. (2013). Kompetensi Dasar Kurikulum 2013.

Patmonodewo. (2000) Pendidikan Anak Prasekolah. Jakarta: Rineka Cipta

Peraturan Menteri Pendidikan Dan Kebudayaan Republik Indonesia. (2013). Implementasi Kurikulum Pedoman Umum Pembelajaran Nomor 81a Tahun 2013. Jakarta: Depdikbud

Prastowo, Andi, (2012) Panduan Kreatif Membuat Bahan Ajar Inovatif. Jakarta: DIVA Press.

Prastowo, Andi. (2013) Pengembangan Bahan Ajar Tematik. Jogjakarta: Diva Press.

Purwanto M. N., (2001) Prinsip-prinsip dan Teknik Evaluasi Pengajaran. Bandung: PT Remaja Rosdakarya.

Pusat Bahasa Kemdiknas. (2008) Kamus Besar Bahasa Indonesia (online). http://pusatbahasa.kemdiknas.go.id/kbbil

Raisamo, Roope. (2006) Design and Evaluation of a Tactile Memory Game for Visually Impaired Children. University of Tampere, Finland. Interacting with Computers 19 (2007) 196-205.

Rifa, Iva. (2012) Koleksi Games Edukatif di Dalam dan Luar Sekolah. Jogakarta: FlashBooks.

Sanjaya, Wina. (2008) Strategi Pembelajaran: Berorientasi Standar Proses Pendidikan. Jakarta: Kencana Prenada Media Group.

Slameto. (1999) Evaluasi Pendidikan. Jakarta: PT Bumi Aksara

Slamteto. (2003) Belajar dan Faktor-faktor yang Mempengaruhi. Jakarta:Rineka Cipta.

Soetjiningsih. (1995) Tumbuh Kembang Anak. Surabaya: Lab Ilmu Kesehatan: Universitas Airlangga.
Solso. (1995) Cognitif Psychology. Boston. Allyn and Bacon.

Sudono. (1995) Alat Bermain dan Sumber Belajar TK. Jakarta: Departemen Pendidikan Nasional.

Sudjana dan Rvai. (2007) Media Pengajaran. Bandung: Sinar Baru Algensindo.

Sudjana, Nana. (2012) Penilaian Hasil Proses Belajar Mengajar. Bandung: PT Remaja Rosdakarya.

Sudjiman, Panuti. (1984) Kamus Sastra. Jakarta: Gramedia

Sugiyono, Prof. Dr. (2009) Metode Penelitian Kuantitatif dan Kualitatif. Bandung: Alfabeta.

Sungkono. (2003) Pengembangan Bahan Ajar. Yogyakarta: FIP UNY.

Suwarno, Wiji. (2006) Dasar-dasar Ilmu Pendidikan. Jogjakarta: Ar-ruzz media

Tedjasaputra, Mayke. (2007) Kepemimpinan dalam Manajemen. Jakarta: Raja Grafindo Persada.

Thiagarajan, Semmel, DS and Semmel M.I. (1974) Instructional Develompment for Training Teacher of Exceptional Children. A Source Book. Blomington: Center for Innovation on Teaching the Handicapped.

Trianto. (2007) Model Pembelajaran Terpadu dalam Teori dan Praktek. Jakarta: Prestasi Pustaka Publisheer

Trianto. (2010) Pengantar Penelitian Pendidikan bagi Pengembangan Profesi Pendidikan dan Tenaga Kependidikan. Jakarta: Kencana. 